\title{
STRATEGI PENANGANAN BANJIR ROB KOTA PEKALONGAN
}

\author{
Slamet Miftakhudin \\ Badan Perencanaan Pembangunan, Penelitian dan Pengembangan Daerah Kota Pekalongan \\ Email: miftahpekalongan2013@gmail.com
}

\begin{abstract}
Pekalongan City is located in the lowlands of the northern coast of Java Island, experiencing tidal flooding with increasing frequency and area of inundation. Inundation due to tidal flooding that occurred in 2018 amounted to 1,391 hectares (29.97\% of the total area) in 2020 increasing to 1,730 hectares (37.27\% of the total area). The problem of tidal flooding occurred in 3 (three) subdistricts covering 11 (eleven) Villages. National Medium-Term Development Plan (RPJMN) 20202024 mandates a major coastal protection project for 5 (five) urban areas including Greater Pekalongan. Various efforts have been made by various parties, including the Central Government, Central Java Provincial Government, Pekalongan City Government, Non-Governmental Organizations, Academics and other stakeholders to deal with the problem of tidal flooding in Pekalongan City. Seeing the dynamics of handling tidal floods in Pekalongan City carried out by various parties, it is necessary to research on strategies for handling tidal floods in Pekalongan City so that the handling carried out can be synergized and achieve targets effectively and efficiently. The purpose of this study was to formulate the strategy of tidal flood management in Pekalongan City and to determine the factors that influence. By analyzing Strengths, Weaknesses, Opportunities and Threats, the best strategy for handling tidal flooding in Pekalongan City will be obtained. The results of the study indicate the need for cooperation and coordination with various parties, community involvement and improvement of Human Resources to optimize the handling of tidal flooding in Pekalongan City.
\end{abstract}

Keywords: Flood, tidal flood, Pekalongan

\section{PENDAHULUAN}

Kota Pekalongan terletak pada posisi 650

42" - 6 55' 44" Lintang Selatan dan 109

37'55" - 109 42'19' Bujur Timur terdiri atas 4 (empat) wilayah kecamatan, yaitu Kecamatan Pekalongan Utara, Kecamatan Pekalongan Timur, Kecamatan Pekalongan Selatan, dan Kecamatan Pekalongan Barat. Batas-batas administratif sebagai berikut:

- Sebelah utara : Laut Jawa

- Sebelah timur : Wilayah Kabupaten Batang

- Sebelah selatan: Wilayah Kabupaten Pekalongan, Kabupaten Batang

- Sebelah barat : Wilayah Kabupaten Pekalongan

Luas wilayah Kota Pekalongan adalah 4.642 (empat ribu enam ratus empat puluh dua) hektar. Jarak terjauh dari wilayah utara ke wilayah selatan $\pm 9 \mathrm{Km}$ dan dari wilayah barat ke wilayah timur $\pm 7 \mathrm{Km}$. Kota Pekalongan terdiri dari 4 kecamatan dan pada mulanya 47 kelurahan menjadi 27 kelurahan. Sesuai dengan Peraturan Daerah Nomor 8 Tahun 2013 tentang Penggabungan Kelurahan di Lingkungan Pemerintah Kota Pekalongan, secara administratif Kota Pekalongan terbagi menjadi 4 kecamatan dan 27 kelurahan (diberlakukan per 1 Januari 2015) dengan jumlah penduduk sebesar 307.150 penduduk pada tahun 2020 . Penggabungan kelurahan tersebut ditujukan untuk meningkatkan pelayanan kepada masyarakat secara efektif dan efisien, melaksanakan fungsi pemerintahan secara efisien serta meningkatkan pemberdayaan masyarakat dalam rangka mewujudkan kesejahteraan masyarakat.

Secara topografis, Kota Pekalongan terletak di dataran rendah pantai utara Pulau Jawa, dengan ketinggian lahan antara 0 meter di atas permukaan laut (dpl) pada wilayah bagian utara dan 6 meter dpl pada wilayah bagian selatan. Ditinjau dari kemiringan lahan, kota Pekalongan termasuk daerah yang relatif datar, 
yaitu dengan kemiringan lahan rata - rata antara $0-5 \%$. Kondisi ini secara topografis akan menyulitkan pengaturan saluran drainase, karena persentase kemiringan lahan relatif kecil. Akibatnya di beberapa kawasan Kota Pekalongan sering mengalami gangguan genangan banjir, sementara di sisi utara wilayah Kota Pekalongan, yang berbatasan dengan kawasan pesisir pantai mengalami bencana rob dengan frekuensi dan luasan genangan yang meningkat. Tantangan lain dalam penanganan banjir rob di Kota Pekalongan adalah terjadinya penurunan tanah (land subsidence) dan kenaikan muka air laut (sea level rise).

Pemerintah Pusat, Pemerintah Provinsi Jawa Tengah, Pemerintah Kota Pekalongan, lembaga swadaya masyarakat, akademisi serta stakeholder lain telah melakukan berbagai upaya untuk menangani permasalahan banjir rob di Kota Pekalongan. Namun demikian, banjir rob masih akan tetap mengancam Kota Pekalongan ke depan.

Melihat dinamika penanganan banjir rob di Kota Pekalongan yang dilakukan berbagai pihak, perlu adanya penelitian tentang strategi penanganan banjir rob di Kota Pekalongan sehingga penanganan yang dilakukan dapat tersinergi dan mencapai target secara efektif dan efisien. Oleh karena itu, disusunlah strategi penanganan banjir rob Kota Pekalongan.

\section{GAMBARAN BANJIR ROB DAN PENANGGULANGANNYA}

Dalam Rencana Aksi Nasional Adaptasi Perubahan Iklim (RAN-API) Kota Pekalongan merupakan salah satu daerah yang memiliki nilai tertinggi sebagai kota percontohan RANAPI dengan nilai 5. Kota Pekalongan masuk dalam wilayah rentan terhadap perubahan iklim dalam RAN-API meliputi banjir, rob, air bersih, sanitasi, dan kekeringan.

Berdasarkan potensi ancaman bencana maka terdapat 4 (empat) potensi bencana di wilayah Kota Pekalongan yaitu bencana banjir rob, bencana banjir, bencana abrasi dan bencana angin puting beliung. Keempat ancaman tersebut merupakan ancaman bagi wilayah Kecamatan Pekalongan Utara. Ancaman bencana, bukan lagi hanya pada kawasan di wilayah Kecamatan Pekalongan
Utara saja, tetapi juga menjadi ancaman bagi keseluruhan kecamatan lainnya yaitu Kecamatan Pekalongan Barat, Pekalongan Selatan, dan Pekalongan Timur. Ancaman untuk keempat kecamatan tersebut adalah banjir. Banjir menjadi potensi yang besar karena topografi wilayah Kota Pekalongan yang sangat datar dan merupakan kawasan muara dari beberapa sungai dari kawasan hulu di daerah lainnya.

Dampak akibat fenomena banjir ini semakin masif terjadi dan cenderung meningkat secara signifikan sebagai salah satu contoh adalah genangan akibat banjir rob yang terjadi pada tahun 2018 sebesar 1.391 hektar $(29,97 \%$ dari luas wilayah) pada tahun 2020 meningkat menjadi 1.730 hektar $(37,27 \%$ dari luas wilayah).

Adapun data genangan yang terjadi di Kota Pekalongan dari beberapa tahun terakhir disajikan dalam tabel sebagai berikut :

Tabel 1 Genangan Banjir dan Rob di Kota Pekalongan Tahun 2016-2020

\begin{tabular}{ccc}
\hline No & Tahun & Luas Genangan (hektar) \\
\hline 1 & 2015 & 1.920 \\
2 & 2016 & 1.870 \\
3 & 2017 & 1.396 \\
4 & 2018 & 1.391 \\
5 & 2019 & 1.057 \\
6 & 2020 & 1.730 \\
\hline
\end{tabular}

Sumber : RPJMD Kota Pekalongan 2021 - 2026

Permasalahan banjir rob terjadi pada 3 (tiga) kecamatan di Kota Pekalongan meliputi 11 (sebelas) kelurahan yaitu Kelurahan Kandang Panjang, Kelurahan Panjang Baru, Kelurahan Panjang Wetan, Kelurahan Padukuhan Kraton, Kelurahan Krapyak, Kelurahan Degayu, Kelurahan Pasirkratonkramat, Kelurahan Tirto, Kelurahan Pringrejo, Kelurahan Kauman, dan Kelurahan Klego. Wilayah yang masih mengalami genangan rob tersebut merupakan kawasan yang berada di pesisir utara dan sekitar Sungai Bremi, Meduri, Kupang (Kali Loji), Sungai Banger serta Sungai Gabus.

Salah satu program penanganan rob dan banjir dengan lokus di Kota Pekalongan sesuai dengan Perpres 79 Tahun 2019 adalah:

- Pengendalian banjir Sistem Sungai Loji/ Pekalongan/Kupang. 
- Pengendalian banjir Sistem Sungai Sengkarang.

- Pengendalian Banjir dan Rob.

- Penyempurnaan Sistem Banjir dan Rob.

Dalam Rencana Pembangunan Jangka Menengah Nasional (RPJMN) 2020 - 2024 salah satu targetnya adalah pengurangan risiko bencana di 20 provinsi dengan risiko bencana tinggi. Berkaitan dengan hal tersebut RPJMN 2020-2024 mengamanatkan Major Project pengaman pantai 5 (lima) kawasan perkotaan meliputi Jakarta Raya, Cirebon Raya, Pekalongan Raya, Semarang Raya dan Surabaya Raya.

Permasalahan banjir rob yang terjadi seiring dengan terjadinya penurunan tanah (land subsidence) dan kenaikan muka air laut (sea level rise). Land subsidence atau amblesan merupakan penurunan muka tanah yang dapat diakibatkan oleh berbagai macam cara. Menurut Whittaker dan Reddish (1989), secara umum faktor penyebabnya antara lain dapat dikelompokkan menjadi 2 (dua) yaitu berdasarkan kondisi geoteknik yaitu pengambilan air tanah, konsolidasi alami, aktivitas pertambangan dan beban bangunan serta berdasarkan kondisi geologi yaitu faktor tektonik.

Penurunan tanah yang terjadi di Kota Pekalongan menurut berbagai informasi adalah sebagai berikut :

- LAPAN (2017 - 2020): $7 \mathrm{~cm} /$ tahun

- Dr. Hery Andreas ITB (2018) : 10 - 20 cm / tahun

- LSM Kemitraan (2018) : $25-34 \mathrm{~cm} \mathrm{/}$ tahun

- Pengamatan Patok Badan Geologi Stadion Hoegeng : 5,7 cm (Maret 2020 - Maret 2021)

Kenaikan muka air laut merupakan fenomena yang terjadi secara periodik sehingga dapat dilihat melalui pasang surut yang terjadi di suatu perairan. Kenaikan muka air laut di Pekalongan sebesar 4,3 mm/tahun (Syafreai Adi Iskandar et al., 2020). Pengaruh penurunan muka tanah menjadi faktor paling tinggi dibandingkan dengan kenaikan muka air laut terhadap perubahan luas genangan banjir rob.

Dalam mewujudkan visi Kota Pekalongan yaitu "Mewujudkan Kota Pekalongan yang
Lebih Sejahtera, Mandiri dan Religius" terdapat 2 (dua) misi yang berkaitan erat dengan penanganan banjir rob di Kota Pekalongan yaitu misi ke-3 (tiga): Mewujudkan Lingkungan Pemukiman yang Nyaman; dan misi ke-4 (empat): Mewujudkan Sarana dan Prasarana Perkotaan berdasarkan Prinsip Pembangunan Kota yang Berkelanjutan.

Tantangan terbesar dalam penanganan banjir rob oleh Pemerintah Kota Pekalongan adalah keterbatasan Pemerintah Kota Pekalongan dalam hal sumber daya baik meliputi pendanaan dan sumber daya manusia. Infrastruktur yang diperlukan untuk menanggulangi dampak banjir rob memerlukan anggaran yang besar, sedangkan kemampuan Pemerintah Kota Pekalongan relatif kecil dalam hal ini. Sumber daya manusia yang terlibat yang dimiliki pemerintah daerah dalam mengatasi persoalan ini pun masih mengalami kekurangan, terutama tenaga ahli yang bisa memberikan pemikiran dalam pengambilan keputusan. Selain itu tantangan lainnya adalah kesiapan sumber daya manusia di tingkat masyarakat untuk adaptasi terhadap budaya baru sebagai dampak banjir rob.

Berbagai upaya telah dilakukan berbagai pihak baik Pemerintah Pusat, Pemerintah Provinsi Jawa Tengah, Pemerintah Kota Pekalongan, lembaga swadaya masyarakat, akademisi serta stakeholder lain untuk menangani permasalahan banjir rob di Kota Pekalongan.

Upaya penanganan banjir rob secara terintegrasi juga menjadi agenda percepatan ekonomi kawasan sebagaimana dijabarkan dalam Peraturan Presiden nomor 19 Tahun 2019, antara lain :

- Pengendalian Banjir Sistem Sungai Loji / Pekalongan / Kupang (Kota Pekalongan dan Kabupaten Pekalongan dengan rencana investasi sebesar Rp. 300 Milyar dari APBN),

- Pengendalian Banjir Sistem Sungai Sengkarang (Kota Pekalongan dan Kabupaten Pekalongan dengan rencana investasi sebesar Rp. 250 Milyar dari APBN),

- Pengendalian Banjir dan Rob (Kota Pekalongan dan Kabupaten Batang dengan 
rencana investasi sebesar Rp. 500 Milyar dari APBN),

- Penyempurnaan Sistem Banjir dan Rob (Kota Pekalongan dan Kabupaten Pekalongan dengan rencana investasi sebesar Rp. 500 Milyar dari APBN),

- Sistem Penyediaan Air Minum (SPAM) Regional Petanglong sistem Kali Boyo untuk melayani Kabupaten Batang dan Kota Pekalongan dengan kapasitas rencana sebesar 450 liter / detik.

Pemerintah Kota Pekalongan juga telah menyusun Revisi Masterplan Drainase Kota Pekalongan Tahun 2020 sebagai pedoman dalam penataan sistem drainase kota yang lebih terarah. Selain itu pada tahun 2020 juga telah ditetapkan Peraturan Daerah Nomor 9 Tahun 2020 tentang Perubahan Atas Peraturan Daerah Kota Pekalongan Nomor 30 Tahun 2011 tentang Rencana Tata Ruang Wilayah (RTRW) 2009-2029 sebagai tuntutan atas perubahan kebijakan dan dinamika pembangunan nasional, Provinsi Jawa Tengah, Kota Pekalongan dan daerah sekitarnya yang mempengaruhi penataan ruang wilayah Kota Pekalongan. Tujuan revisi RTRW adalah terwujudnya kota kreatif yang didukung perdagangan dan jasa, industri, dan perikanan, yang nyaman, aman, produktif, serta berkelanjutan.

Pihak lain non pemerintah seperti akademisi di antaranya Universitas Diponegoro, Institut Teknologi Bandung, Institut Pertanian Bogor banyak terlibat dalam berbagai kajian/studi. Bahkan dalam beberapa waktu terakhir melibatkan Massachusetts Institute of Technology (MIT) dari Amerika Serikat.

Lembaga Swadaya Masyarakat (LSM) yang ikut terlibat dalam penanganan banjir rob di Kota Pekalongan di antaranya adalah LSM Bintari melalui Kajian Loss and Damage Banjir Rob Pekalongan Raya (2016) serta pembuatan pilot project MCK adaptif (2020). Mercy Corps Indonesia turut membantu dalam berbagai kajian melalui program flood resilience city untuk Kota Pekalongan di antaranya dengan membuat kajian kerentanan (2020) dan saat ini masih berjalan dengan kajian-kajian terkait, dengan melibatkan berbagai stakeholder mulai dari akademisi hingga kementerian maupun pihak lain. LSM
Kemitraan juga turut membantu Kota Pekalongan melalui Aksi Adaptasi Perubahan Iklim dengan pendekatan 3S yaitu Safekeeping - Surviving - Sustaining (Melindungi Mempertahankan - Melestarikan). Selain itu Hoogheemraadschap van Schieland en Krimpenerwaard (HHSK) Belanda melalui Witteven Bos juga telah membuat kajian tentang Pekalongan Coastal Zone, Coastal Erotion and Flooding in the city of Pekalongan yang dibiayai oleh HHSK Belanda tahun 2016.

\section{TUJUAN PENELITIAN}

Tujuan penelitian ini adalah untuk merumuskan strategi penanganan banjir rob di Kota Pekalongan dan untuk mengetahui faktorfaktor yang mempengaruhi strategi penanganan banjir rob di Kota Pekalongan.

\section{METODE PENELITIAN}

Metode penelitian yang digunakan dalam penelitian ini adalah penelitian deskriptif dengan pendekatan kualitatif. Dalam pendekatan kualitatif yang terpenting adalah bagaimana menentukan informan kunci yang sarat informasi sesuai dengan fokus penelitian (Moleong, 2011). Metode kualitatif dapat digunakan untuk mengungkap dan memahami sesuatu di balik fenomena yang sedikitpun belum diketahui.

Teknis pengumpulan data yang digunakan yaitu informasi pihak terkait dan dokumentasi. Informan yang dipilih adalah berbagai pihak yang terlibat dalam penanganan banjir rob di Kota Pekalongan yang telah/tengah dilakukan baik dari instansi terkait maupun LSM dan akademisi.

Analisis yang digunakan dalam penelitian ini menggunakan metode SWOT (Strength, Weakness, Opportunity and Threat). Dengan menganalisis Kekuatan (Strength), Kelemahan (Weakness), Peluang (Opportunity) dan Ancaman (Threat) akan diperoleh strategi terbaik dalam penanganan banjir rob di Kota Pekalongan.

Matriks SWOT merupakan cara sistematik untuk mengidentifikasi keempat faktor yang tercakup dalam analisis yang menggambarkan kecocokan paling baik di antaranya. Analisis ini didasarkan pada asumsi bahwa suatu strategi 
akan memaksimalkan kekuatan dan peluang, serta meminimalkan kelemahan dan ancaman.

Matriks SWOT digunakan untuk mengembangkan empat tipe alternatif strategi yaitu SO (strengths- opportunities), strategi WO (weaknesses- opportunities), strategi ST (strengths-threats), dan strategi WT (weaknesses- threats). Terdapat empat tahapan dalam membentuk matriks SWOT yaitu:

- Mencocokkan kekuatan internal dengan peluang eksternal dan mencatat resultan strategi SO.

- Mencocokkan kelamahan internal dengan peluang eksternal dan mencatat resultan strategi WO.

- Mencocokkan kekuatan internal dengan ancaman eksternal dan mencatat resultan strategi ST.

- Mencocokkan kelemahan internal dengan ancaman dan mencatat resultan strategi WT.

Analisis ini dapat menghasilkan empat kemungkinan alternatif strategis (Rangkuti, 2009:19-31) seperti ditunjukkan dalam tabel 2 Matriks SWOT berikut ini:

Tabel 2 Matriks SWOT

\begin{tabular}{|c|c|c|}
\hline & Strengths & Weaknesses \\
\hline EFAS & $\begin{array}{l}\text { Tentukan } 4 \\
\text { faktor-faktor } \\
\text { kekuatan } \\
\text { Internal }\end{array}$ & $\begin{array}{l}\text { Tentukan } 4 \\
\text { faktor-faktor } \\
\text { kelemahan } \\
\text { Internal }\end{array}$ \\
\hline Opportunities & Strategi SO & Strategi WO \\
\hline $\begin{array}{l}\text { Tentukan } 4 \\
\text { faktor-faktor } \\
\text { peluang } \\
\text { eksternal }\end{array}$ & $\begin{array}{l}\text { Ciptakan } \\
\text { strategi yang } \\
\text { menggunakan } \\
\text { kekuatan utk } \\
\text { memanfaatkan } \\
\text { peluang }\end{array}$ & $\begin{array}{l}\text { Ciptakan } \\
\text { strategi yang } \\
\text { meminimalkan } \\
\text { kelemahan utk } \\
\text { memanfaatkan } \\
\text { peluang }\end{array}$ \\
\hline Treaths & Strategi ST & Strategi WT \\
\hline $\begin{array}{l}\text { Tentukan } 4 \\
\text { faktor } \\
\text { ancaman } \\
\text { ekternal }\end{array}$ & $\begin{array}{l}\text { Ciptakan } \\
\text { strategi yg } \\
\text { menggunakan } \\
\text { kekuatan } \\
\text { untuk } \\
\text { mengatasi } \\
\text { ancaman }\end{array}$ & $\begin{array}{l}\text { Ciptakan } \\
\text { strategi yg } \\
\text { meminimalkan } \\
\text { kelemahan } \\
\text { dan } \\
\text { menghindari } \\
\text { ancaman }\end{array}$ \\
\hline
\end{tabular}

\section{HASIL DAN PEMBAHASAN}

Berdasarkan penelitian mengenai strategi penanganan banjir rob di Kota Pekalongan, yang dilakukan maka disusun analisis SWOT sebagai berikut:

Tabel 3 Analisis SWOT Penanganan Banjir Rob Pekalongan

\begin{tabular}{rlr}
\hline No & Uraian & Skor \\
\hline Kekuatan & \\
\hline 1 & $\begin{array}{l}\text { Visi dan Misi Walikota Pekalongan 2021 - } \\
\text { 2026 }\end{array}$ & 5 \\
2 & $\begin{array}{l}\text { Ketersediaan sumber dana pemerintah pusat } \\
\text { dan provinsi }\end{array}$ & 5 \\
3 & $\begin{array}{l}\text { Tersedianya Review Masterplan Drainase } \\
\text { Kota Pekalongan tahun 2020 }\end{array}$ & 4 \\
4 & $\begin{array}{l}\text { Tersedianya Perda no 9 tahun 2020 tentang } \\
\text { Revisi RTRW }\end{array}$ & 3 \\
\hline
\end{tabular}

\begin{tabular}{rlc}
\hline \multicolumn{1}{c}{ Jumlah } & 17 \\
\hline Kelemahan & 3 \\
\hline 1 & Kualitas SDM kurang memadai & 4 \\
2 & Keterbatasan APBD Kota Pekalongan & 4 \\
3 & Sarana dan prasarana kurang memadai & 4 \\
4 & Sistem drainase yang belum optimal & 15 \\
\hline \multicolumn{2}{c}{ Jumlah }
\end{tabular}

Ancaman

1 Kurangnya kesadaran masyarakat terhadap 3 lingkungan

2 Kenaikan Muka Air Laut (Sea Level Rise) 5

3 Penurunan permukaan tanah (Land 5 Subsidence)

4 Penyempitan dan Pendangkalan Sungai 5 /Saluran/Badan air dan Berkurangnya resapan air

\begin{tabular}{|c|c|c|}
\hline \multirow{2}{*}{\multicolumn{3}{|c|}{ Peluang }} \\
\hline & & \\
\hline 1 & $\begin{array}{l}\text { Adanya kerjasama dan dukungan dari } \\
\text { instansi pemerintah lain yang terkait }\end{array}$ & 5 \\
\hline 2 & $\begin{array}{l}\text { Pemerintah Kota Pekalongan, Pemerintah } \\
\text { Kabupaten Pekalongan, Pemerintah } \\
\text { Kabupaten Batang, Pemerintah Provinsi, } \\
\text { Pemerntah Pusat dan DPRD Kota } \\
\text { Pekalongan mendukung dan membantu } \\
\text { dalam penanganan banjir Kota Pekalongan }\end{array}$ & 5 \\
\hline 3 & $\begin{array}{l}\text { Adanya partisipasi masyarakat Kota } \\
\text { Pekalongan untuk dalam ikut penanganan } \\
\text { banjir rob }\end{array}$ & 3 \\
\hline 4 & $\begin{array}{l}\text { Adanya kerjasama dengan LSM, Akademisi } \\
\text { maupun Pemerintah Belanda dalam } \\
\text { penanganan banjir rob }\end{array}$ & 4 \\
\hline & Jumlah & 17 \\
\hline
\end{tabular}

Keterangan: Digunakan skoring 1 s.d. 5 (skala Likert)

Dari hasil identifikasi tersebut selanjutnya peneliti akan melakukan langkah-langkah analisis sesuai Matriks SWOT untuk memperoleh strategi SO, strategi WO, strategi ST dan strategi WT. 
Tabel 4 Matriks SWOT

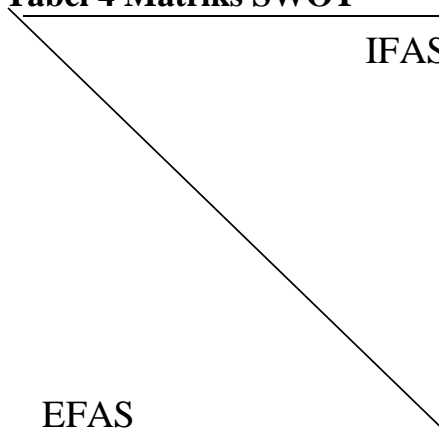

Opportunities

1. Adanya kerja sama dan dukungan dari instansi pemerintah lain yang terkait

2. Pemerintah Kabupaten Pekalongan, Pemerintah Kabupaten Batang, Pemerintah Provinsi, Pemerntah Pusat dan DPRD Kota Pekalongan mendukung dan membantu dalam penanganan banjir Kota Pekalongan

3. Adanya partisipasi masyarakat Kota Pekalongan untuk dalam ikut penanganan banjir rob

4. Adanya kerja sama dengan LSM, Akademisi maupun Pemerintah Belanda dalam penanganan banjir rob

Treaths

1. Kurangnya kesadaran masyarakat terhadap lingkungan

2. Kenaikan muka air laut (sea level rise)

3. Penurunan permukaan tanah (land subsidence)

4. Penyempitan dan pendangkalan sungai /saluran/badan air dan berkurangnya resapan air

\section{Weaknesses}

1. Visi dan Misi Walikota Pekalongan 2021 - 2026

2. Ketersediaan sumber dana pemerintah pusat dan provinsi

3. Tersedianya Review Masterplan Drainase Kota Pekalongan tahun 2020

4. Tersedianya Perda No. 9 Tahun 2020 tentang Revisi RTRW

\section{Strategi SO}

1. Peningkatan kerja sama dengan instansi pemerintah baik Pusat maupun provinsi dan kabupaten tetangga serta pihak lain untuk mendukung pencapaian visi misi walikota

2. Sosialisasi kepada masyarakat terkait regulasi serta masterplan drainase untuk meningkatkan partisipasi masyarakat
1. Kualitas SDM kurang memadai

2. Keterbatasan APBD Kota Pekalongan

3. Sarana dan prasarana kurang memadai

4. Sistem drainase yang belum optimal

\section{Strategi WO}

1. Kerja sama peningkatan SDM dengan pihak akademisi dan Pemerintah Belanda yang lebih maju dalam penanganan banjir

2. Koordinasi secara intensif dengan pemerintah pusat dan provinsi dalam rangka percepatan pelaksanaan Perpres 79 tahun 2019

3. Kerja sama dengan LSM, akademisi dan Pemerintah Belanda untuk peningkatan studi dan kajian yang terintegrasi dalam penanganan banjir rob

4. Pelibatan masyarakat yang lebih luas termasuk swasta untuk meningkatkan kepedulian terhadap lingkungan

\section{Strategi ST}

1. Sosialisasi regulasi dan rencana pemerintah untuk meningkatkan kesadaran masyarakat

2. Konsistensi implementasi Perda RTRW untuk peningkatan daya dukung dan daya tampung lingkungan

\section{Strategi WT}

1. Pelibatan masyarakat untuk ikut memelihara sarana prasaran yang telah terbangun dan untuk lebih peduli terhadap isu-isu lingkungan

2. Peningkatan kerja sama dengan berbagai pihak dalam rangka penanganan isu terkait sea level rise dan land subsidence

3. Optimalisasi sistem drainase 


\section{SIMPULAN DAN SARAN}

\subsection{Simpulan}

Berdasarkan analisis SWOT yang dilakukan maka telah disusun Strategi Penanganan Banjir Rob Kota Pekalongan sebagai berikut :

1) Peningkatan kerja sama dengan instansi pemerintah baik pusat maupun provinsi dan kabupaten tetangga serta pihak lain untuk mendukung pencapaian visi misi walikota.

Kerja sama yang saat ini mulai berjalan baik perlu ditingkatkan mengingat penanganan banjir rob tidak dapat dilakukan sendiri oleh Pemerintah Kota Pekalongan. Berbagai keterbatasan yang dimiliki oleh Kota Pekalongan dapat diatasi dengan kerja sama yang dilakukan terhadap pihak-pihak yang memiliki kemampuan.

2) Sosialisasi kepada masyarakat terkait regulasi serta masterplan drainase untuk meningkatkan partisipasi masyarakat.

Masterplan drainase dan rencana penataan kota perlu disosialisasikan agar mendapatkan dukungan yang lebih luas serta meningkatkan peran serta masyarakat. Masterplan drainase juga merupakan acuan secara lengkap dan menyeluruh atas kondisi permasalahan dan potensi sistem drainase sebagai dasar perencanaan jaringan drainase di wilayah Kota Pekalongan.

3) Kerja sama peningkatan SDM dengan pihak akademisi dan Pemerintah Belanda yang lebih maju dalam penanganan banjir. Untuk meningkatkan kapasitas SDM perlu kerja sama dengan berbagai pihak yang berpengalaman dalam penanganan banjir rob. Pemerintah Belanda yang berpengalaman lebih dari 700 tahun dalam penanganan banjir dapat menjadi rujukan. Tata kelola, sistem drainase, budaya masyarakat Belanda bisa diadaptasi dengan menyesuaikan kondisi di Kota pekalongan.

4) Koordinasi secara intensif dengan pemerintah pusat dan provinsi dalam rangka percepatan pelaksanaan Perpres No. 79 Tahun 2019.
Pelaksanaan penanganan banjir rob oleh Pemerintah Pusat melalui Balai Besar Wilayah Sungai (BBWS) Pemali Juana perlu dikoordinasikan lebih intensif mengingat pada tahun 2021 direncanakan akan dimulai. Hal ini untuk mengantisipasi kesulitan yang berpotensi terjadi pada saat implementasi di lapangan. Selain itu agenda lain dalam Perpres No. 79 Tahun 2019 terkait SPAM Regional Kaliboyo perlu mendapat dukungan berbagai pihak karena berkaitan dengan pemenuhan kebutuhan air bersih bagi Kota Pekalongan untuk mensubstitusi penggunaan air bawah tanah yang saat ini banyak digunakan oleh masyarakat.

5) Kerja sama dengan LSM, akademisi dan Pemerintah Belanda untuk peningkatan studi dan kajian yang terintegrasi dalam penanganan banjir rob.

Inisatif berbagai LSM, akademisi dan Pemerintah Belanda perlu diapresiasi dan didorong untuk memberikan masukan kebijakan bagi Pemerintah dalam isu banjir rob ini.

6) Pelibatan masyarakat yang lebih luas termasuk swasta untuk meningkatkan kepedulian terhadap lingkungan.

Tumbuhnya berbagai komunitas peduli lingkungan di Kota Pekalongan menunjukkan kepedulian warga yang semakin meningkat akan kondisi lingkungan hidup. Meningkatnya komunitas peduli ini akan dapat memberikan dampak positif bagi masyarakat yang saat ini masih rendah kesadarannya.

7) Sosialisasi regulasi dan rencana pemerintah untuk meningkatkan kesadaran masyarakat.

Upaya peningkatan kesadaran masyarakat dalam bentuk yang lebih mudah diterima diperlukan, di antaranya adalah melalui media sosial maupun media lain yang digandrungi masyarakat. Perlu edukasi melalui berbagai cara baik melalui kesenian maupun melalui tokoh agama serta tokoh masyarakat. 
8) Konsistensi implementasi Perda RTRW untuk peningkatan daya dukung dan daya tampung lingkungan.

Perda RTRW yang mengatur kebijakan penataan ruang wilayah kota diharapkan konsisten dalam pelaksanaannya untuk menjaga harmonisasi antara lingkungan dan dinamika pembangunan.

9) Pelibatan masyarakat untuk ikut memelihara sarana prasarana yang telah terbangun dan untuk lebih peduli terhadap isu-isu lingkungan.

Pasca terbangunnya infrastruktur penanganan banjir rob, yang diperlukan adalah operasional dan pemeliharaan yang baik. Pelibatan masyarakat secara aktif akan sangat membantu dalam keberlangsungan infrastruktur terbangun.

10) Peningkatan kerja sama dengan berbagai pihak dalam rangka penanganan isu terkait sea level rise dan land subsidence.

Banjir rob yang saat ini semakin meluas karena meningkatnya muka air laut dan penurunan tanah. Beberapa kajian/studi yang dibuat oleh akademisi maupun lembaga pemerintah dapat ditindaklanjuti dengan kerja sama oleh Pemerintah Kota Pekalongan agar memperoleh masukan yang tepat untuk merumuskan kebijakan dalam penanganan isu ini.

11) Optimalisasi sistem drainase.

Salah satu faktor penting yang dominan perannya dalam mengatasi permasalahan banjir rob adalah sistem drainase. Sarana dan prasarana yang ada perlu dioptimalkan untuk mengurangi dampak yang terjadi. Sampai dengan tahun 2020, Pemerintah Kota Pekalongan memiliki 21 (dua puluh satu) stasiun pompa yang yang dioperasikan untuk menangani banjir. Stasiun pompa dan infrastruktur lain baik berupa saluran drainase, pintu pengendali banjir, tanggul dan sebagainya juga perlu peningkatan sesuai kebutuhan dalam masterplan drainase.

\subsection{Saran}

Berdasarkan kondisi permasalahan dan hasil kajian, maka kami sampaikan rekomendasi kebijakan sebagai berikut :
1) Peningkatan kerja sama dengan instansi pemerintah baik Pusat maupun Provinsi dan Kabupaten tetangga serta pihak lain untuk mendukung pencapaian visi misi walikota.

Salah satu forum yang saat ini tersedia di tingkat kawasan adalah Tim Koordinasi Pengelolaan Sumber Daya Air (TKPSDA) Pemali Comal yang beranggotakan perwakilan Pemerintah Pusat, Provinsi dan Kabupaten/Kota serta masyarakat/LSM yang mengadakan sidang secara rutin. Rekomendasi dari sidang TKPSDA diharapkan mampu memberikan solusi atas permasalahan pengelolaan sumber daya air terpadu yang tidak terbatas pada wilayah administratif.

2) Sosialisasi kepada masyarakat terkait regulasi serta masterplan drainase untuk meningkatkan partisipasi masyarakat.

Dalam masterplan drainase Kota Pekalongan terdapat usulan Kelembagaan pengelolaan drainase Kota Pekalongan yaitu Badan Pengelola Sistem Drainase Kota Pekalongan (BPSDKP) dimana diperlukan adanya keterlibatan masyarakat dalam memelihara dan mengoperasionalkan sistem drainase sekunder-tersier yang akan disusun sesuai Rencana Induk Pemberdayaan Masyarakat.

3) Kerja sama peningkatan SDM dengan pihak akademisi dan Pemerintah Belanda yang lebih maju dalam penanganan banjir. Pemerintah Provinsi Jawa Tengah telah melakukan kerjasama dengan IHE Delft Belanda untuk meningkatkan kapasitas SDM dalam pengelolaan sumber daya air. Kerja sama ini melalui implementasi short course maupun pengiriman pegawai untuk menempuh strata 2 pada IHE Delft. Langkah serupa juga telah diikuti oleh Kabupaten Brebes, untuk itu Pemerintah Kota Pekalongan sebaiknya perlu mengirimkan tenaga terbaiknya untuk menimba ilmu terkait pengelolaan sumber daya air.

4) Koordinasi secara intensif dengan pemerintah pusat dan provinsi dalam rangka percepatan pelaksanaan Perpres No. 79 Tahun 2019. 
Beberapa paket pekerjaan yang direncanakan BBWS Pemali Juana saat ini masih dalam proses pelelangan. Untuk mengantisipasi potensi permasalahan $\mathrm{di}$ lapangan perlu koordinasi secara intensif dengan berbagai stakeholder yang terlibat mengingat di saat yang sama juga terdapat penanganan baik oleh Pemerintah Pusat melalui proyek Wisata Laut dan program KOTAKU, Pemerintah Provinsi yang akan membangun tanggul pantai dan tanggul sungai serta Pemerintah Kota Pekalongan yang melakukan peningkatan sistem drainase. Koordinasi dapat dilakukan Pemerintah Kota Pekalongan, melalui Bappeda dan DPUPR, dengan Pemerintah Provinsi Jawa Tengah, melalui Dinas Pekerjaan Umum Sumber Daya Air dan Tata Ruang serta Pemerintah Pusat melalui BBWS Pemali Juana.

5) Kerja sama dengan LSM, akademisi dan Pemerintah Belanda untuk peningkatan studi dan kajian yang terintegrasi dalam penanganan banjir rob.

Beberapa kerja sama yang dirintis oleh Pemerintah Kota Pekalongan saat ini mulai membuahkan hasil dengan berbagai partisipasi para pihak tersebut baik berupa kajian maupun intervensi fisik. Pemerintah Kota Pekalongan perlu memperluas dan meningkatkan kerja sama dengan pihak tersebut sesuai kebutuhan yang diperlukan sehingga penanganan banjir rob terintegrasi dengan baik.

6) Pelibatan masyarakat yang lebih luas termasuk swasta untuk meningkatkan kepedulian terhadap lingkungan.

Kepedulian masyarakat yang meningkat terhadap isu perlu direspon oleh Pemerintah Kota Pekalongan. Pemerintah Kota Pekalongan dapat melakukan kegiatan kolaborasi dengan berbagai komunitas tersebut. Selain itu pihak swasta diajak terlibat penanganan banjir rob melalui program Corporate Social Responsibilities (CSR).

7) Sosialisasi regulasi dan rencana Pemerintah untuk meningkatkan kesadaran masyarakat.
Pemanfaatan media yang dimiliki Pemerintah baik media televisi, radio, media cetak maupun media sosial dapat menjadi sarana sosialisasi dengan program ataupun tayangan yang lebih mudah dipahami dan diterima oleh masyarakat.

8) Konsistensi implementasi Perda RTRW untuk peningkatan daya dukung dan daya tampung lingkungan.

Kesesuaian antara Rencana Tata Ruang Wilayah dan implementasi pemanfaatan ruang sangat diperlukan untuk menjaga harmonisasi antara lingkungan dan dinamika pembangunan. Tim Koordinasi Pengendalian Tata Ruang Daerah (TKPRD) diharapkan konsisten dengan regulasi yang menjadi acuan dalam penataan kota.

9) Pelibatan masyarakat untuk ikut memelihara sarana prasarana yang telah terbangun dan untuk lebih peduli terhadap isu-isu lingkungan.

Komunitas peduli lingkungan dapat menjadi embrio untuk menjadi partner strategis dalam peran pemeliharaan sarana prasarana terbangun dan program konservasi lingkungan.

10) Peningkatan kerja sama dengan berbagai pihak dalam rangka penanganan isu terkait sea level rise dan land subsidence.

Isu land subsidence Kota Pekalongan dan daerah pantura yang menghangat akhirakhir ini harus dapat dikelola dengan baik oleh Pemerintah Kota Pekalongan. Pemerintah Kota Pekalongan sebaiknya melakukan kerja sama dengan para pihak tersebut agar isu tersebut tidak berdampak negatif bagi Kota Pekalongan.

11) Optimalisasi sistem drainase.

Sistem drainase yang ada harus dipertahankan kinerjanya dengan memelihara sarana dan prasarana, sedangkan untuk mengoptimalkan sistem drainase dibutuhkan pendanaan, peran aktif stakeholder dalam operasional dan pemeliharaan serta peningkatan infrastruktur. 


\section{REFERENSI}

Aniesya Septyaningrum, 2018. Strategi Pengendalian Banjir di Kelurahan Kapas Madya Baru Kecamatan Tambaksari Kota Surabaya, Undergraduate thesis, Universitas 17 Agustus 1945

Cahyadi, A., Marfai, M. A., Mardiatno, D., dan Nucifera, F. 2013. Pemodelan Spasial Bahaya Banjir Rob Berdasarkan Skenario Perubahan Iklim dan Dampaknya di Pesisir Pekalongan. Jurnal bumi Lestari., 3(2): 244-256.

Endah Murniningtyas, 2013, Indonesia National Action Plan on Climate Change Adaptation (RAN-API), Presented in COP 19 - UNFCCC.

Hery Andreas, 2019. Tidal Inundation ("Rob"), Sea Level Rise, Land Subsidence dan Isu Terkait di Wilayah Pekalongan. Disampaikan pada Seminar "Sosialisasi UU No. 12 tentang APBN 2019 dalam Penanggulangan Banjir dan Rob di Pantura Pekalongan” tanggal 5 Agustus 2019.

Inne Septiana Permatasari, 2012. Strategi Penanganan Kebencanaan di Kota Semarang (Studi Banjir dan Rob). Journal Of Public Policy And Management Review, Volume 1 Nomor 1 Tahun 2012.

Moleong, L.J. 2011. Metodologi Penelitian Kualitatif Edisi Revisi. Bandung: PT. Remaja Rosdakarya.

Muh. Askal Basir, 2018. Strategi Penanggulangan Resiko Bencana pada Badan Penanggulangan Bencana Daerah Kabupaten Buton. MEDIALOG: Jurnal Ilmu Komunikasi, Volume I, No. I, Februari 2018.

Rangkuti, Freddy. 2009. Strategi Promosi yang Kreatif dan Analisis. Kasus. Integrated Marketing Communication. Jakarta : PT. Gramedia Pustaka Utama.

Syafrei Adi Iskandar, Muhammad Helmi, Muslim, Sugeng Widada dan Baskoro Rochaddi, 2020. Analisis Geospasial Area
Genangan Banjir Rob dan Dampaknya pada Penggunaan Lahan Tahun 2020 2025 di Kota Pekalongan Provinsi Jawa Tengah. Indonesian Journal of Oceanography [August] [2020] Vol 02 No: 03 ISSN:2714-8726.

Whittaker D.N, and Reddish D.J, (1989), "Subsidence Occurence, Prediction and. Control", DME Univ of Notthingham, Elsiver, New York.

Peraturan Presiden Nomor 79 Tahun 2019, tentang Peraturan Presiden (PERPRES) tentang Percepatan Pembangunan Ekonomi Kawasan Kendal Semarang - Salatiga - Demak - Grobongan, Kawasan Purworejo - Wonosobo Magelang - Temanggung, dan Kawasan Brebes - Tegal - Pemalang

https://peraturan.bpk.go.id/Home/Details/12613 9/perpres-no-79-tahun-2019

Peraturan Presiden Nomor 18 Tahun 2020, tentang Rencana Pembangunan Jangka Menengah Nasional $2020-2024$

https://jdih.setkab.go.id/PUUdoc/176020/Perpre s_Nomor_18_Tahun_2020.PDF

Peraturan Daerah Kota Pekalongan Nomor 9 Tahun 2020 tentang Perubahan Atas Peraturan Daerah Kota Pekalongan Nomor 30 Tahun 2011 Tentang Rencana Tata Ruang Wilayah Kota Pekalongan Tahun 2009-2029.

Rencana Pembangunan Jangka Menengah Daerah Kota Pekalongan 20212026.

Witteveen Bos, 2016. Pekalongan Coastal Zone Coastal erosion and flooding in the city of Pekalongan, Hoogheemraadschap van Schieland en Krimpenerwaard.

PT. Studi Teknik, 2020. Laporan Akhir Penyusunan Revisi Masterplan Drainase Kota Pekalongan, Tahun 2020 